\title{
The Concept of Green Management in the Management of CSR: Implementation study of CSR Programs at Azana Hotel Group
}

\author{
Dicky Sumarsono ${ }^{1,2,3^{*}}$, Bani Sudardi ${ }^{1}$, Warto Warto ${ }^{1}$, dan Wakit Abdullah ${ }^{1}$ \\ ${ }^{1}$ Postgraduate Program in Cultural Studies, Sebelas Maret University, Ir. Sutarmi 36A Street, \\ Surakarta 57126, Indonesia \\ ${ }^{2}$ AAS College of Economics, Slamet Riyadi no. 361 street, Surakarta 57161, Indonesia \\ ${ }^{3}$ Victoria Hotel School, Honggowongso 57 Street, Honggowongso Square A1, Surakarta 57151, \\ Indonesia
}

\begin{abstract}
The change in CSR is not only a matter of fulfilling the obligation of the Limited Liability Company Law, but also the issue of CSR that becomes a matter of justice and natural balance. The Word Commission on Environment requires every company in business activity to always consider the principles of sustainable development that rely on economic benefits (profit), environmental sustainability (planet) and social welfare (people). This study uses qualitative methods, with data collection methods through observation, interview, and documentation study. While the analysis used is descriptive qualitative analysis. According to research findings; the first is CSR programs in Azana Hotel Group includes; education, empowerment of the poor and save the environment. Second, from the implementation of CSR, Azana Hotel Management realized the important role of local communities in hotel operation towards the society, which in turn will bring huge profits to the company. Third, the implementation of environmental program in the form of greening on critical lands can actually educate and manage the employees, hotel guests, and society. So, it can increase the awareness of the importance of a sustainable natural environment. Fourth, ethically, the Azana Hotel Group CSR can regulate the behavior of people or groups of people in the company to be sustainable living. Ethics could be understood as moral principles and values that govern the behavior of people or groups related to what is right or wrong.
\end{abstract}

\section{Introduction}

The area or scope of implementing CSR (Corporate Social Responsibility) program can be varied depending on what goal the company wants to achieve. The allocation of CSR is designated in the terms of education, poverty reduction, health, labor, environment, and others. The current trend, which is the focus of CSR program is in the area of

${ }^{*}$ Corresponding author: dickysumarsono@gmail.com 
environmental conservation. A lot of parties have implemented environmentally friendly programs in the operational work of the company[1]. The orientation of environmental sustainability is highly considered by the hotel industry because all related aspects are closely related to the environment in hotel operation[2]. In daily operation, a lot of water and soap are needed for washing the guests' towels. Therefore, in an effort to reduce the effect of environmental pollution, the hotel gives a suggestion for the guests to use the same towels (by not requesting a new towel). However, this effort is only in the form of suggestion or solicitation, and cannot be coercive to the guests. Moreover, the efficiency of operating costs can be used to save the environment through CSR programs.

CSR programs are not only a matter of fulfilling the obligation of Law Number 40 year 2007 concerning Limited Liability Company. Particularly Article 74 paragraph (1), which explains that a company that runs its business activities in the field and/or is related to natural resources, must carry out Social and Environment Responsibility. However, the issue of CSR is a matter of justice and natural balance. Corporations have been viewed as institutions or individuals who take the most portion of this nature. Since it takes the most portion, many other natural and human beings are harmed. So, The Word Commission on Environment requires every company in business activities to always consider the principles of sustainable development that rely on economic growth, environmental protection, and social equity to maintain the natural balance. These principles are known as the Triple Bottom Line (TBL), namely economic benefits (profit), environmental sustainability (planet) and society welfare (people)[1], [3].

Whether we have to admit it or not, the company is a trigger for environmental damage. It can be seen from the company's waste, the noise, the condition and situation of the company when operating, and the pollution that can harm the society. If the society considers that the company does not pay attention to social and environmental aspects, does not give direct contributions to the society, and the society gets the negative impact, then these conditions will create a sense of disbelief in the society and will defame the company. This is a major issue of the need for the company to implement CSR programs.

Azana Group manages 35 hotels, they are Front One Hotel Madura, Front One Hotel Purwodadi, Front One Solo Airport Hotel, Front One Resort Wisma Aji Yogya, Front One Hotel Kediri, Front One Inn Jombang, Azana Greati Diponegoro Surabaya, Azana Saptanawa Resort Gresik, Lotus Hotel Kediri, The Cube Hotel Yogya, De Laxton Hotel Yogya, and Grand Amira Hotel Solo. Those hotels have implemented CSR (Corporate Social Responsibility) programs as a form of commitment to set aside the company's assets to reduce the negative impact during the company operation towards of the all interested parties. The implemented various CSR programs aim to develop a productive society. The CSR Azana Group Hotel is divided into three target groups, namely; (1) Educational Development, (2) Empowerment of the poor society, (3) Save the environment. According to the 3 research objectives, we want to explore about saving the environment deeply. Therefore, the research questions are; "How is the implementation of CSR in the Azana Group, and why Azana Group uses the green management concept as a CSR implementation strategy?"

\section{Materials and Methods}

The type of this study is qualitative research[4]. The data collections are done through (1) observation on objects or targets of CSR programs in the Surakarta area, although the targets are located in various regions, (2) interview with Azana Group management, (3) study from books, journals and progress reports of CSR Azana Group hotels. The writers analyze the data by using interpretative descriptive methods[5-6]. As an interpretative 
parameter, we use the basic framework of green management. The results of this qualitative research will conclude the Azana Group Hotel Implementation in implementing green management in the CSR programs until the phase of why the green management concept is used.

\section{Results and Discussions}

\subsection{Concept of Green Management Hotel}

The issue of environmental damage has been deteriorating lately, changing the corporate management mindset in the CSR program, especially on the global warming issue. The efforts for the environmental rescue that are done by the corporation, called Green Management. Green Management is the managers' responsibility towards the impact of the company's operations on the natural environment [7] Through the green management, the managers will think about the impacts that will affect the nature due to the products[8]. In the hospitality area, for example, there are many ways to do it, starting with a simple one, which is to persuade the hotel guests for not changing the towels every day, to use the construction of hotel buildings that are environmentally friendly. For example, the construction of a cement board can reduce the sun's heat that is entering the room, so that it reduces the air conditioner usage. In addition, the supplying hot water for the guests needs by solar systems, so it does not consume lots of electricity.

There are three levels in implementing a Green Management system by a company, there are the development of environmental rules, system planning for the application of rules, and its practical application. The rules must be contained by the company's commitment to focus on the environment. At the second level, plan the system on the company. And the third is its implementation. [9] gives the example on Les Orangeries Hotel in France, which has been conferred by European Ecolabel because of its environmentally friendly building construction, the hotel park maintenance does not use pesticides, and some products can be recycled and ensure that food is cooked using lowcarbon quality ingredients.From several real actions taken by business people both in the hospitality industry and other industries, it can be categorized as a level or stage of the implementation of Green Management, this stage is The Green Approaches. The following actions stages are categorized as green management.

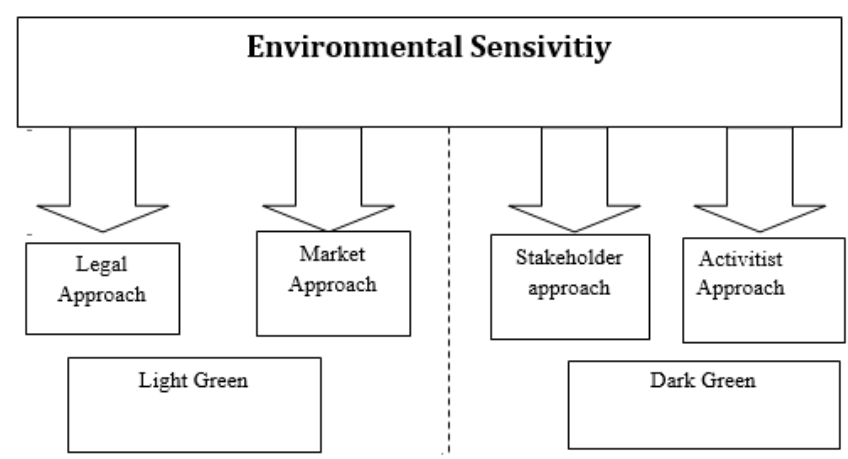

Fig. 1. Environment Sensivity 
From the Figure. 1 can be explained as follows:

1. The legal approach: the actions taken by the company in the environment rescuing are limited to complying with the regulations. The lowest response from responsibility of environmental rescue (social obligation).

2. The market approach: Corporate responsibility in the environment rescue due to the consumers' demand (one-sided only). The intermediate responses in terms of saving the environment (social responsiveness).

3. The stakeholder approach: Corporate responsibility to prioritize the interests of saving the environment to fulfill the various stakeholders (stakeholders) such as employees, distributors, or ecological communities. High response to the environmental rescue.

4. The Activist approach: The response towards the environment is very high and this is the social responsibility. Hotels that have environmental programs start from supply chains with less carbon and recycled products, hotel product designs with the ecofriendly design, and work operations (employees and community).

The above concepts are to measure how high the Azana Group hotel is to carry out social responsibility, whether it is merely fulfilling obligations or indeed having a high commitment to the environmental rescue program.

\subsection{CSR Implementation and Azana Group Commitment}

Azana Hotel Management is a global hotel operator, catering, and restaurant management consulting company. Company that has more than 30 years of experience in the hotel \& restaurant industry, in Indonesia, Singapore, Hong Kong and the Netherlands. Company that has the vision and mission of being "Star" in the hospitality industry service, and the customers' connectivity network with the company. In developing its business, Azana Group collaborates with organizations, educational institutions, online reservations, public and social sectors. Azana Group building core business in the hospitality industry can be traced from the development of Corporate Social Responsibility activities.

Conceptually the scope of CSR can vary depending on what goals a company wants to achieve. Concern for the social environment in the surrounding community as an example can be in the development of non-formal education facilities in the form of libraries that can improve community capacity [10-12]. At present, the CSR carried out by Azana Hotel Goup includes; in the education and health field, empowerment of the poor and saving the environment moreover the present, the area that is the focus of saving the environment. In the management of hotel operations, environmental rescue services are implemented also. For example, every day a lot of water and soap are needed for washing the guest room towels, however, as a form to reduce the effects of environmental pollution, the hotel gives an appeal and education for the guests who sojourns during the stay, so that they use the same hotel towels do not ask for new towels. Although it is only in the form of appeals or persuasion, the education value of environmental rescue internally is emphasized in order to be understood by the guests.

Azana Group's manager, Jatmiko, externally stated that CSR is an important activity that is not only for charity but also a commitment to be responsible for the environment and the surrounding environment. This commitment is indicated by the establishment of a special department, as well as a focused program that prioritizes the environmental safety and community welfare and invites the hotel guests and all colleagues from the hotel to be actively involved in the framework of this sustainable development. By seeing a strong commitment and Corporate Social Responsibility program in the hotel industry, it was not the hotel loss but the program was able to create continuous awareness for employees and all colleagues involved in hotel operations[13,14]. Azana Group management in 
implementing 3 fields of the CSR programs, they are the field of environmental rescue, education and health then empowerment of the poor. Following these are the CSR program activities in the Azana Group in the field of environmental rescue in 12 hotels from 35 hotels in 2017-2018.

Table 1. CSR program from Azana Group

\begin{tabular}{|c|c|c|}
\hline No & Name of The Hotel & Description \\
\hline 1 & Hotel Front One Hotel Madura & Reforestation \\
\hline 2 & Front One Hotel Purwodadi & Reforestation \\
\hline 3 & Front One Hotel Airport Solo & Waste Management \\
\hline 4 & $\begin{array}{c}\text { Front One Resort Wisma Aji } \\
\text { Yogya }\end{array}$ & Waste Management \\
\hline 5 & Front One Hotel Kediri & City Park \\
\hline 6 & Front One Inn Jombang & City Park \\
\hline 7 & Azana Greati Surabaya & Waste Management \\
\hline 8 & Azana Saptawana Resort Gresik & $\begin{array}{c}\text { Coastal Area } \\
\text { Planting }\end{array}$ \\
\hline 9 & Lotus Hotel kediri & City Park \\
\hline 10 & The Cube Hotel Yogya & Recycling \\
\hline 11 & De Laxton Hotel Yogya & Park and Garbage \\
\hline 12 & Grand Amira Hotel Solo & $\begin{array}{c}\text { Slum Area } \\
\text { Facilities }\end{array}$ \\
\hline
\end{tabular}

There are 12 hotels whose CSR are used to improve environmental facilities, ranging from reforestation activities, improvement of city parks around hotels, waste management, and repair of urban slum facilities. Meanwhile 23 hotels, are mostly used for education financing (charity) and the empowerment of the poor through capital assistance and training.

The CSR program for Azana management hotel has many advantages including: (1) Hotel together with group management gain the good image in the eyes of the public because the hotel is considered to care about social issues such as environmental issues and community welfare; (2) the guests participation in the CSR program is very high, and increase the sense of belonging to the program and loyalty then choose the hotel as the priority choice; (3) in the daily operations of the hotel activities, by carrying out environmentally friendly programs, it is actually reduced the costs for the electricity and other energy usage; (4) the existence of the environmental rescue program so that hotels rely on the nature as the selling value, tourists will visit the area continuously and the hotel will still be able to operate for a long time.

\subsection{Green Management Activity in Azana Hotel Management}

The rationale of the Azana Hotel Management (AMH) in implementing the CSR program is that AMH realizes the importance of the role of local communities in hotel operations and the CSR concept that puts forward people, planet, and profit, has a major influence on society which eventually brings huge profits to the company. Initially, CSR activity was only a response to requests for donations from certain communities, organizations or institutions in line with the vision and mission of the social program of the 
AMH group. However, in the development, AMH realized that CSR program with the activity responding to requests for donations was not directed clearly, had no specific objectives achieved and was very difficult to be able to embrace the involvement of both employees and hotel guests.

Since 2014, AMH has created their own social program that has clear directions and wants to increase the participation of employees and hotel guests. In Surakarta, AMH cooperates with the Institute for Community Development Studies (LSPM), a nongovernmental organization in Boyolali, to work on reforestation on critical land in Gunung Madu and Gunung Semar areas of Simo and Klego Districts. AMH is also involved in the slum arrangement around Surakarta's Klitikan Kusumodilagan Market. In Yogyakarta, they work with BEM of campuses to create city parks around hotels and campuses. In Kediri, they work with the community of Jl. Jaksa Agung Suprapto to create a city park. With the program initiated by the management, CSR program becomes more directed and transparent, and the goal is clear, that is to save the environment. This program not only involves employees and the community, but the management also involves customers or guests who have memberships or regular customers. Like the tree planting activities in the area of Gunung Madu and Gunung Semar, Simo. Long before, the management invited guests who became customers, and also offered guests staying at Front One Airport Hotel, Amira Hotel and Azana Hotel. It turned out that this activity was responded by the hotel guests quite enthusiastically because it was carried out on holidays, and the management also provided transportation to the tree planting location.

The implementation of the environmental rescue program in form of reforestation on critical lands can actually educate the management, employees, hotel guests and the direct beneficiary communities on Gunung Madu Simo and raise awareness of the importance of a sustainable natural environment. Even, according to the management of CSR, in the form of planting trees in the coming rain, the elements of stakeholders will be expanded by involving large numbers of teachers and students. In addition, in 2019 they plan to donate money from the efficiency of hotel operations from a predetermined standard. This efficiency is from the components of buying soap, pasta, electricity, water, and recycled products from some go-green items. The component is calculated with the standard before the enactment of green management. And this policy is also socialized to AMH customers.

According to the data of $\mathrm{AMH}$, with targeted and transparent programs, there was a $2 \%$ increase per month in the results collected for CSR programs from customers, guests and employees. This shows that social awareness at the community level has also increased. AMH associates CSR programs in their overall business strategy where this makes the group truly support the community within the hotel environment and this is relevant to the daily operations of employees. What's interesting is that the CSR program for each hotel is not made by the head office but is made and adapted to the needs of the local where the hotel is located so that each General Manager is free to determine a program that is suitable for the local community. From the diversity of CSR programs, the spirit of Responsible Business remains the main base.

\subsection{Green Management as Business Ethics}

In the implementation of green management, the environmental critical issues that need to get the attention of all parties including the industrial world can be raised [7]. Often the implementation can be hampered, because the benefits cannot be felt directly by the company, or even felt unnecessary. One of the approach models to evaluate a company's commitment to the environmental responsibility is the green nuance model. The 
commitments of companies using this approach can be seen with various stages of the depth of activity done. The following is the green nuance approach in four stages.

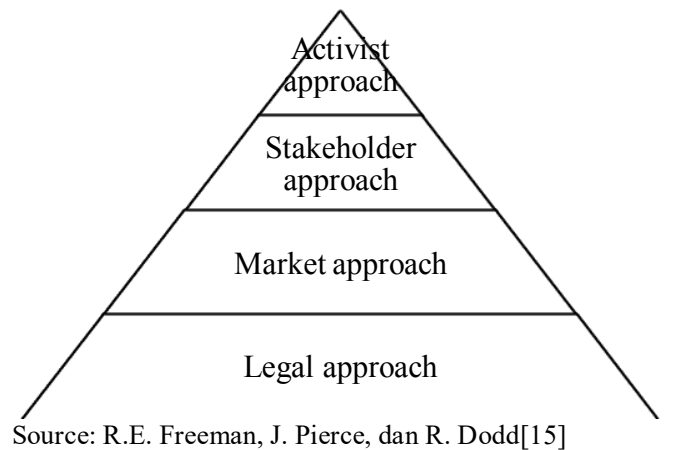

Fig. 2. Pyramid describes the business ethic building

As explained in the previous discussion, this pyramid describes the business ethic building carried out by Azana Hotel Management (Figure.2) namely (1) Legal approach: The company simply does what is needed to fulfill the legal requirements; (2) Market approach: The company provides products that are environmentally friendly because customers want such products, not because of a strong management commitment to the environment; (3) Stakeholder approach: The company tries to respond to environmental issues raised by stakeholders; (4) Activist approach: The company actively seeks ways to conserve resources on earth.

AMH applies green management in their efforts to preserve the environment with the concept of Green Nuance as a philosophical and ethical foundation, as a company culture. The ethic meant is to set the behavior of a person or a group of people in a company to become a Green Nuance as a lifestyle. Ethics is understood as moral principles and values that govern the behavior of people or groups related to what is right or wrong. From the above comprehension, it can be explained that ethics relates to the internal values of the company and forms decisions regarding social responsibility related to the external environment. Ethical issues are present in a situation when the actions taken by an organization can cause benefits or losses to other parties.

According to Baron [16] what is meant by business ethics is the application of the ethical principles applied in relation to the emergence of problems in business. "Business ethics is the application of ethics principles to issues that arise in the conduct of business." The implementation of green management can be raised because of the presence of critical environmental issues that need to get the attention of all parties including the industrial world. Often the implementation can be hampered, because the benefits cannot be felt directly by the company, or even felt unnecessary.

The greening of management, in this aspect the management makes policies, determines the medium- and long-term targets or specific targets in their respective fields and determines the company's overall vision. The company can also adopt ethical practices related to the environment, which can assist in the creation of the company programs so that they can continue to develop. In the organizational structure, anenvironment committee or responsible individual can also be formed. So, one of them is to be involved in a variety of activities based on the product environment strategy.

The company needs to develop environmentally friendly products and products that can be recycled, and create a company image which products are "environment-friendly" starting from the raw material to the final stage of the product. Pay attention to the use of 
resources and replacing/procuring resources, and design sustainable products. The role of the company with stakeholders is to maintain good relations with suppliers who have a commitment to the environment. From the motive above, it can be seen if the movements done by the company are actually strategic or ethical. From the model of green nuance approach in green management, for example at the level of the activist approach, it can be said that the company has conducted business activities ethically, with moral motivation, of saving the environment. Even though the management is aware that the activities that they carry out incur huge costs, but not necessarily bring short-term benefits, but actually can strategically provide long-term benefits. Indeed, often something ethical is not strategic for the company, and conversely, something strategic is often unethical for other parties. The following is an illustration of how the green management approach can be ethical but also ethical, for the achievement of long-term company goals.

\section{Conclusion}

The deal of Green Management is a company's commitment to environmental responsibility. The commitment of the company management prevents and minimizes the negative effects of the company's activities as part of "Business Ethics" where environmental protection, economic growth, and social equality can significantly assimilate the company's activities in accordance with management principles. Improvement and modification of environmental sustainability issues carried out by Azana Hotel Group actually work on three pillars namely, People, Planet and Profit (3P) and looking for ways to balance the $3 \mathrm{P}$ with the Go Green Initiative issue to reduce pollution and carbon emissions leading to the Greenhouse effect on planet Earth. In the implementation of the three pillars (3P) of Azana Hotel Group in its operations they use 3 principles, namely, Recycle, Reduce, and Reuse. These three main activities help reduce the cost of operating the hospitality industry which is ultimately efficient, and can reduce pollution caused by human activities, such as the beauty of the park or many greeneries function to clean the air around the hotel. The use of water to water the plants carried out by the hotel uses bath water processed to water the plants, providing dispensers for soap and shampoo.

\section{References}

1. S. E. Levy and S. Y. Park. J. Hosp. Tour. Manag. 18, 1 (2011).

2. S. Punitha and R. Mohd Rasdi. Asian Soc. Sci 9, 17 (2013).

3. S. Y. Park and S. E. Levy. Int. J. Contemp. Hosp. Manag. 26, 3 (2014).

4. P. Alasuutari. Qual. Inq 2, 4 (1996).

5. I. Dey, Qualitative Data Analysis: A user-friendly guide for social scientists (London, Routledge, 1993)

6. R. C. Richey and J. D. Klein, Design and development research: methods, strategies, and issues (New Jersey, RoutledgeFalmer, 2007)

7. K. H. Lee. J. Asia-Pacific Busv15, 2 (2014).

8. T. Y. Hsiao, C. M. Chuang, N. W. Kuo, and S. M. F. Yu. Int. J. Hosp. Manag 36 (2014).

9. S. P. Robbins and M. Coulter, Management (New Jersey, Pearson Education, 2012)

10. P. Suharso, B. Sudardi, S. T. Widodo, and S. K. Habsari. IOP Conf. Ser. Earth Environ. Sci 116, 1 (2018).

11. P. Suharso, B. Sudardi, S. T. Widodo, and S. K. Habsari. E3S Web Conf. SCiFiMaS 
47 (2018).

12. P. Suharso and S. Sarbini. E3S Web Conf. SCiFiMaS 47 (2018).

13. M. Abram and J. Jarząbek. Ecocycles 2, 1 (2016).

14. S. Y. Park and S. E. Levy. Int. J. Contemp. Hosp. Manag 26, 3 (2014).

15. E. Freeman, J. Pierce, and R. Dodd, Shades of Green: Business Ethics and the Environment (New York, Oxford University Press, 1995)

16. D. P. Baron, Business and its Environment. (London, Prentice Hall, 2000) 